\title{
The internalization context of private health service providers in Europe: Romanian market case study
}

\author{
Mihai VOLINTIRU \\ The Bucharest University of Economic Studies (ASE), Bucharest, Romania \\ mihai@volintiru.com
}

\begin{abstract}
This paper looks at the opportunities and constraints of the private healthcare sector in Europe today. Using the case study of Romania, I explore the attractiveness of foreign and domestic private capital investments in companies that supply healthcare services. In the aftermath of the economic crisis, the private provision of healthcare services has been growing steadily, and there are clear signs in the common market that the liberalisation policies will only increase the attractiveness of such investment still. As large-scale investment projects like general hospitals require large amounts of upfront investment, it is only natural to assume that at least part of this capital will be obtained through internationalisation decision of foreign companies. This paper also presents in depth a comparative overview of the two most developed private healthcare provisions in Romania: dialysis centres and medical laboratories. Part of their success is due to their longstanding relationship with the National Health Insurances House. These medical services generally benefit from large scale public subsidies that support the delivery of private health care provision in Romania. The private providers of medical services in Romania have recorded a steady annual growth dynamics over the past years. In the case of private medical laboratories, the geographical distribution shows a heavy concentration on the main municipalities in Romania. This gives us a perspective on the limited ability of private providers to penetrate smaller markets without the incentive of public subsidies. The Romanian market has proved to be an attractive destination for foreign investors in the medical sector. This is driven in part by the quantitative limitations of the public sector that is struggling with an overload in urban areas, but also by the attractiveness of private health insurance packages offered by many private health care providers. The main international health care providers in Romania that constitute the case studies of this paper are: Medlife, Regina Maria, Medicover, Sanador and Gral Medical.
\end{abstract}

Keywords: investments, private sector, health care providers, Romania, standardization, market share, dialysis centres, medical laboratories.

\section{Introduction}

This paper analyses the market dynamics of private suppliers of laboratory and clinical health services in Romania and the opportunities for foreign direct investments in this sector. Through recent market liberalization measures in Romania, the health and care sector is developing networks of private service providers. The process is however taking place is a very slow pace, and the perspectives are uncertain as to what the immediate next steps will be. I argue that the potential for international investments is large, especially in large scale projects, and that the main location remains the capital city of Bucharest due to its potential market size.

This paper develops an overall perspective on investment incentives and opportunities in the Romanian health care market. Firstly, it presents an overall assessment of the medical care needs and suppliers in Romania. Secondly, it presents the case study of the largest private health care market in Romania: the dialysis centres. Thirdly, it explores the most territorially diverse and second largest private health care market in Romania: medical laboratories. I also bring into discussion the elements that allow private service providers to survive in the Romanian market, and I refer in particular to the very high reliance these companies have on public funding derived from the National Health Insurance House (i.e. CNAS). 
Still, even in the absence of public transfers for such services, it is not a surprise that these two type of health services are the most developed in the Romanian market as the private capital is also more inclined towards these activities. According to a recent assessment on private equity attractiveness in the health services (i.e. clinics, hospitals, medical laboratories), the out-patients clinics (such as dialysis centres) and the medical labs have been the only ones regarded by the McKinsey assessment team as being "very attractive", in contrast to hospitals/in-patients units, care homes/elderly care, or nonmedical service providers ${ }^{1}$. The opportunity for investment positive margins in this sector are high given the overall demographic distribution in Europe, and the increasing policy support for private service providers. The liberalisation of the health care market might bring about a sort of homogenisation in the quality of services provided that national regulation and public spending could not.

There are two large tendencies in the Central and Eastern Europe at this moment concerning the health private sector. On one hand there is a gradual process of liberalization of health services, with the increasing higher number of private actors in this sector which was under the traditional State monopoly for a very long time. Privatisation in the medical sector is tricky in the post-communist context where an extensive state funded welfare system has been put in place by the party-state governments of the previous regime. As the generation that matured under communism reaches the age of increased reliance on health and general care services, they are still expecting the State to be the main provider of such services. This process is also even more difficult to achieve in this context because of the lower purchasing power or spending capacity of the patients in this region. On the other hand, there is a larger panEuropean dynamic of large scale investments in private health and care infrastructure in the form of specialized or regional hospitals that involve large upfront investments, and usually a public-private partnership (PPP).

\section{Current context and literature review}

Foreign direct investments in the medical sector have not been prevalent in the European Union. Only the Hungarian Agency for Foreign Direct Investments (HIPA) deploys an explicit activity in the field of attracting FDI in the medical technology sector (Horobet and Popovici 2017). Nevertheless, in the Romanian case we find an increasingly attractive destination for private capital-both domestic and foreign, in the case of the medical sector.

Investments in healthcare have a very high profitability nowadays as they reach global total returns to shareholders of approximately 15\%. McKinsey pointed out earlier this year that the European healthcare market is a "golden opportunity" for private equity $^{2}$. At the same time a number of European investments have been increasingly targeting this sector, weather through traditional cohesion programmes such as the Regional Operational Programme (POR) or the more novel instruments focused mainly of profitable investments in European development.

One of the few projects that have been greenlighted for funding under the recent European Fund for Strategic Investments (EFSI) in Romania is that of the private health care provider Regina Maria. The funding decision under the Junker Plan (i.e. European Commission's Investment Plan for Europe) is explained by the European Investment

\footnotetext{
1 https://www.mckinsey.com/industries/private-equity-and-principal-investors/our-insights/european-healthcarea-golden-opportunity-for-private-equity

2 https://www.mckinsey.com/industries/private-equity-and-principal-investors/our-insights/european-healthcarea-golden-opportunity-for-private-equity
} 
Bank (EIB) representatives as follows: "In the past seven years, Regina Maria has made CAPEX investments of over EUR 70 million in expansion, modernisation and new technology acquisition (...) Through our facilities and strong reputation for healthcare quality at European standards, we are playing an increasingly important role in the development of the medical services sector." ${ }^{3}$. According to the press release of EIB, the project to upgrade and expand its network of outpatient and inpatient facilities mainly outside the capital city involves the extension and modernisation of the network. ${ }^{4}$ It involves: the construction and renovation of two hospitals and 15 outpatient centres, including polyclinics, laboratories and imaging centres. In addition to increasing healthcare capacity and improving the quality of medical services this project will lead to the creation of about 2,000 jobs during its operation. ${ }^{5}$

Eurofound's analysis of EQLS micro-data reflects a high incidence of poor health amongst the bottom quartile income. Within this low income group, bad health is reported by $17 \%$ of the respondents in comparison to the top income quartile where bad health is reported by only $5 \%$. Furthermore, the trend of polarization is increasing as bad health reporting increased by 3 percentage points in the lower income quartile in between 2007 and 2010, while it remained the same in the higher income quartile amongst EU member states.

The privatization process is taking hold of the medical sector in Europe with a higher prevalence after the crisis hit back in 2009. Various authors point to the relation between the financial crisis and austerity measures on one hand, and the increased relevance of private capital investments in the medical sector (Hermann, C., \& Flecker, J. 2013, Karanikolos et al 2013).

In the Romanian case study, the privatization process took roots even before the economic crisis, with the two most advanced areas of health care that are provided in the private sector being dialysis (Nikolic and Maikisch 2006) and medical laboratories (Volintiru 2016). While the first is achieved as a consensus at the political level to institute a national dialysis programme that involves the insurance coverage to private as well as public providers, the latter is the result of liberalization measures and outsourcing on behalf of public hospitals. Most of the patients or clients of private medical laboratories in Romania are referred to them by their General Physician (GP) medic de familie (Volintiru 2017). Them too are covered to an extensive degree by eligible payments through the National Health Insurance System. While the liberalization of the private healthcare service providers was initially intended to maintain public budget coverage only for a short period of time, to ensure the transition to a new market driven system, it has failed to reach the full private transaction form yet.

\section{Empirical findings}

In terms of the overall dynamics of the Romanian private health care market, we can see that the number of private companies is slowly but surely increasing over the course of the past years.

This paper also contains a descriptive statistical analysis of the market concentration in Romania, at the regional level, of private health service providers. It is important to ascertain the territorial concentration patterns of private health care

\footnotetext{
${ }^{3}$ http://www.eib.org/infocentre/press/releases/all/2017/2017-165-eu-bank-supports-expansion-of-regina-mariaprivate-healthcare-network-in-romania.htm

4 idem.

5 Idem.
} 
providers as it is in the centers with the highest density of private market exchanges that we can expect the presence of foreign economic agents through direct or indirect investments.

I firstly looked at the dialysis market in Romania and the dynamic of the main private suppliers in this sector, as it is here that the largest turnover and profits are recorded. Patients have the right to choose their dialysis provider and the law also allows private providers authorized by the Ministry of Health to provide dialysis services through the national dialysis program. The dialysis service market has risen on the back of the increase in public funds allocated to the national dialysis program, which public hospitals and private hospitals can contract. The budget for the national renal replacement program increased from year to year to 869.43 million lei in 2015, from 803.11 million lei in 2014 and 745 million lei in 2013.

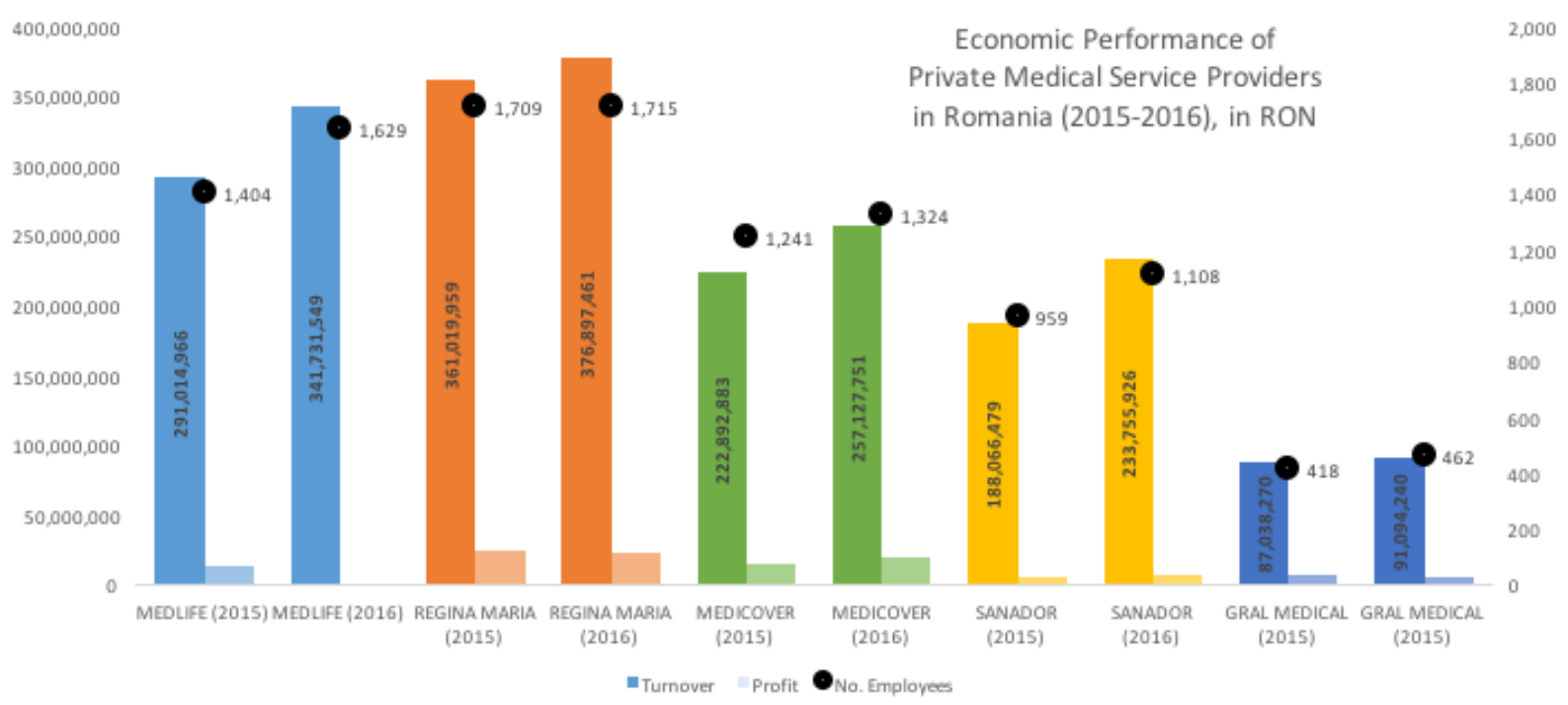

Figure 1. Economic Performance of Private Medical Service Providers in Romania (20152016), RON

Source: compiled by the author from Ministry of Public Finances data

While Medlife is one of the largest private health care service provider in Romania, in general services, it is less profitable than the largest dialysis private provider Fernesius Group. This proves that the niche subsectors of the Romanian healthcare system that have benefitted from state funding from the National Health Insurance House (CNAS) have a better market chance than greenfield investments.

Looking at the past couple of years, the financial state of the main healthcare providers in Romania shows a clear growing trend for most of them. The main private general healthcare service providers (i.e. private clinics and hospitals network) in Romania are: Medlife, Regina Maria, Medicover, Sanador and Gral Medical. Medlife increased its turnover substantially, from 291 mil. RON in 2015 to 341 mil. RON in 2016, its profits were null in 2016 due to large acquisitions. Regina Maria maintained a steady profit share of approximately 20 mil. RON. Medicover grew both in turnover-from 222 mil. RON in 2015 to 257 mil. RON in 2016, and in profits-from 15 mil. RON in 2015, to 19 mil. RON in 2016. Sanador, the only Romanian owned private healthcare service provider on the Romanian market, grew both in turnover-from 188 mil. RON in 2015 to 233 mil. RON in 2016, and in profits, from 5 mil. RON in 2015 to 7 mil. RON in 2016. Finally, Gral Medical Services recorded the most modest growth in this category, increasing its total turnover from 87 mil. RON in 2015 to $91 \mathrm{mil}$. RON in 2016, and seeing its profit decrease from 7 mil. RON in 2015 to 5 mil. RON in 2016. 


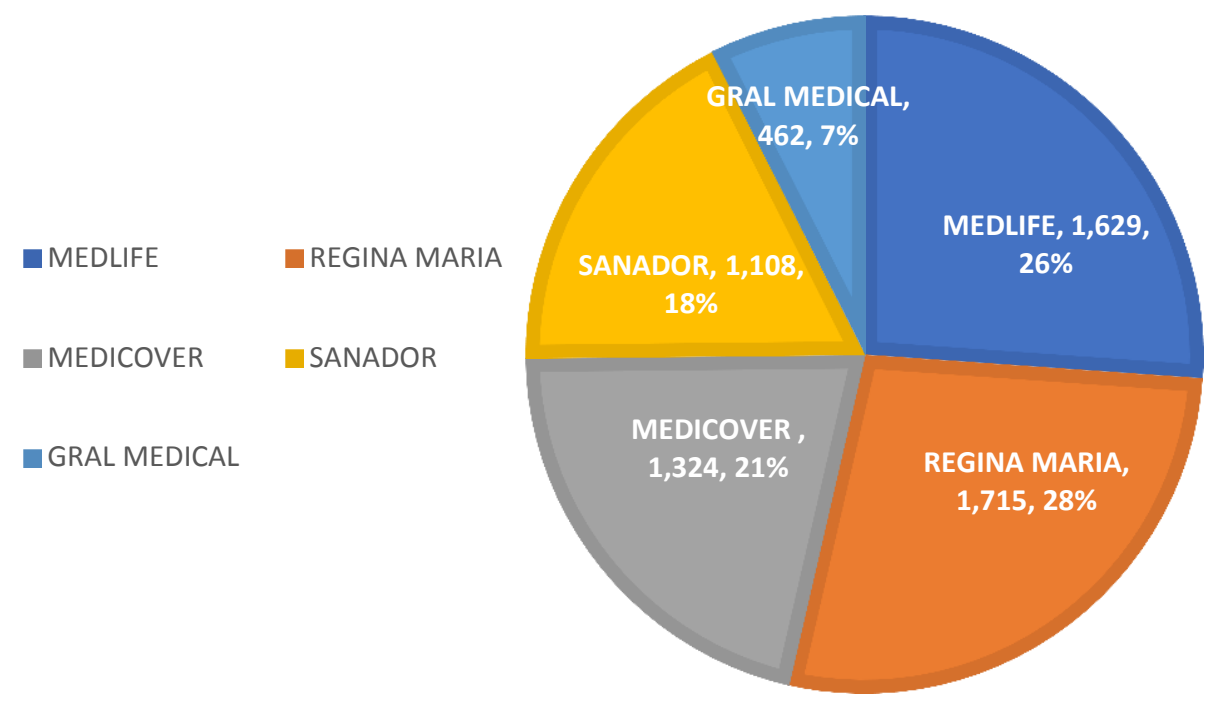

PICBE $\mid 1042$

Fig. 2. Employees number and relative share in main general healthcare private providers in Romania (2016)

Source: compiled by the author from Ministry of Public Finances data

When looking at the employment share, we can see that to a large degree the overall turnover of the medical is reflected in the employment figures. The largest employer on the market currently is Regina Maria with 1,715 employees, followed by Medlife with 1,629, then Medicover with 1,324, Sanador with 1,108, and Gral Medical with 462. In total, the general private healthcare providers in Romania currently employ more than 6,000 persons. The total turnover of Medlife cannot be properly approximated due to the fact that the company invested all of its profits in the acquisition of the majority package of shares (51\%) of different Romanian companies that activate in the private medical business sector.

The internationalisation process behind these private economic agents in the Romanian healthcare sector is clear when we look at the ownership structure of these companies. Medlife's majority ownership package belongs to the Romanian Marcu family, but the minority shares have been owned by private equity companies - V4C and IFC. These have recently existed the business by listing their shares on the stock exchange. The value of Medlife's stocks has been increasing, starting at 26 RON in 2016, and being currently listed at approximately $30 \mathrm{RON}$. Regina Maria is currently owned by MEP Capital Investments who purchased the company from Advent-both foreign registered companies. Medicover belongs to the ABC Medicover Holding BV from Sweden. The "smaller" private general healthcare service providers in RomaniaSanador and Gral Medical are owned by Romanians.

Public and private dialysis providers compete for nearly 11,900 patients who need dialysis to live and for a total budget of almost 900 million lei provided by the National Health Insurance House within the national dialysis programme.

Fresenius is the leader of the local dialysis market. The Fresenius Group's dialysis centers had cumulated net business of over 337.19 million lei. The German group also recorded a profit margin of $4.8 \%$ in 2014 , and $5 \%$ in 2015 . It has one of the densest 
territorial presences in this dialysis healthcare sector with 34 regional centers ${ }^{6}$ that are operated by separate companies in each county for insurance purposes.

The dialysis sector in Romania is currently making a much larger financial impact than even the largest private general healthcare service providers, due to a much easier market access through the insurance of the National Health System. The foreign owned Fresenius Group recorded in 2016 a total turnover of 535 mil. RON, and a profit level of 38 mil. RON. It employs a total of 1,382 persons and is clearly the dominant player in a highly concentrated market.

The internationalization process is evident in the dialysis services too, as the largest player in this subsector is owned by the German Fresenius Medical Care Deutschland $\mathrm{GmbH}$. The second largest dialysis private service providers, Diaverum is also owned by a foreign company-DIAVERUM SWEDEN, and it has acquired smaller domestic dialysis private service providers in Craiova and other localities in their efforts to expand and implant on the Romanian market. This strategy is mirroring the extensive network of the Fresenius Group. Finally, the third important private dialysis service provider in Romania, Avitum is also a branch of a foreign company-the German B. Braun Melsungen AG.

The stock options of the largest private health care operator in Romania, Medlife, have started to trade at the Bucharest Stock Exchange on the $21^{\text {st }}$ of December 2006. As a result of the biggest initial public offer (IPO) from Romanian private company, the health care sector has started to attract attention from international investors as a profitable business investment. 8 mil. shares have been offered to the public in the listing of Medlife, at the initial price of 26 RON per share, which has almost doubled over the course of the following couple of year.

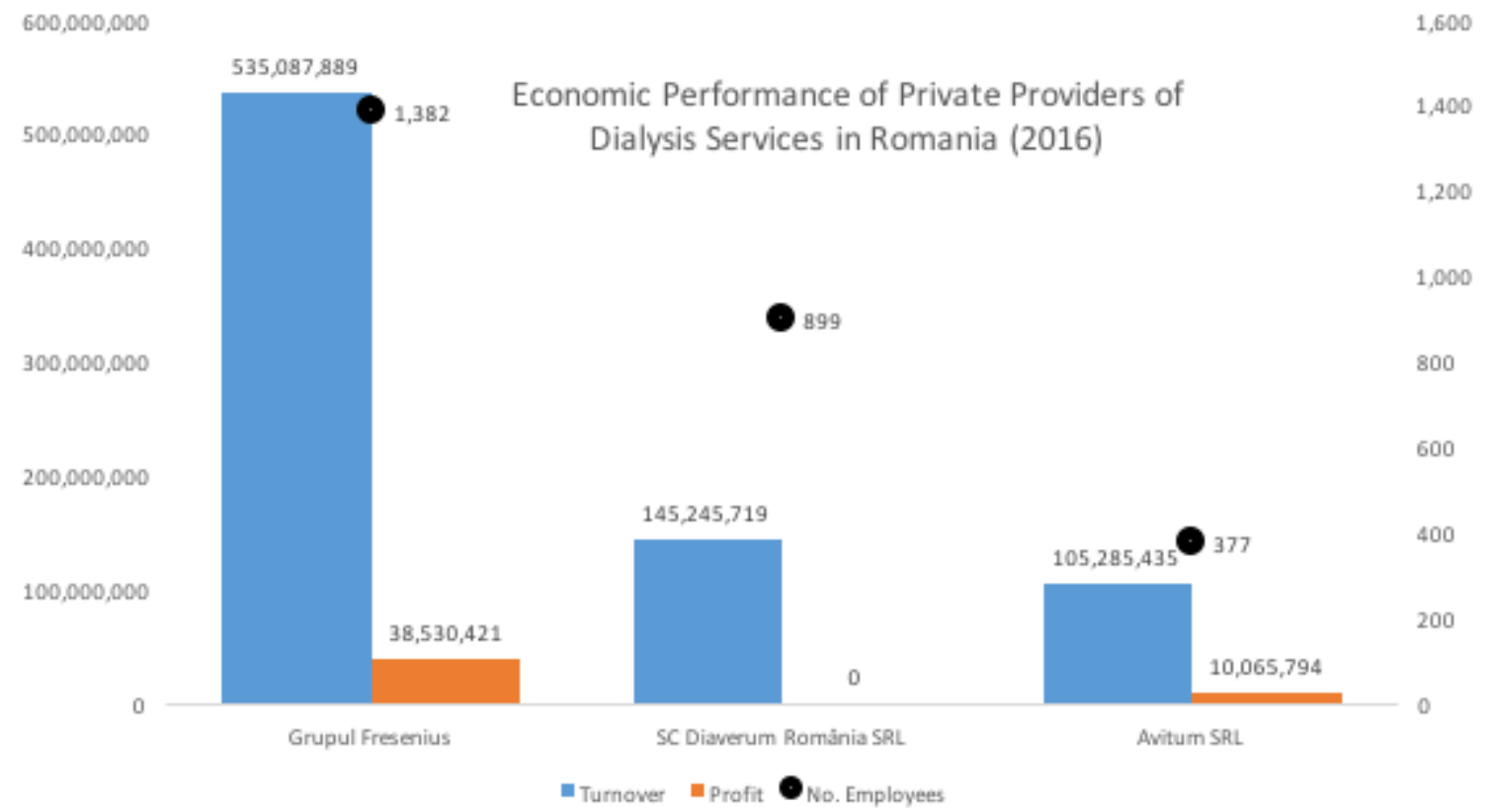

Figure 3. Economic Performance of Private Providers of Dialysis Services in Romania (2016)

Source: compiled by the author from Ministry of Public Finances data

\footnotetext{
${ }^{6}$ Bacău, Baia Mare, Bârlad, Braşov, București, Câmpulung, Constanţa, Cluj, Craiova, Giurgiu, Iaşi, Suceava, Piteşti, Oradea, Onești, Târgoviște, Slobozia, Tulcea, Ploiești, Deva, Satu Mare, Drobeta Turnu Severin, Râmnicu Vâlcea, Alba Iulia, Piatra Neamţ, Timişoara, Dej, Medgidia, Rădăuţi, Sighet, Zalău, Iaşi, Vaslui, Turda.
} 
I also use as an expressive illustration of the private providers supply in the health sector in Romania the pilot case study of private medical laboratories, as this is the area that has reached the highest number of private economic providers. Medical laboratories represent the most developed private providers' territorial network.

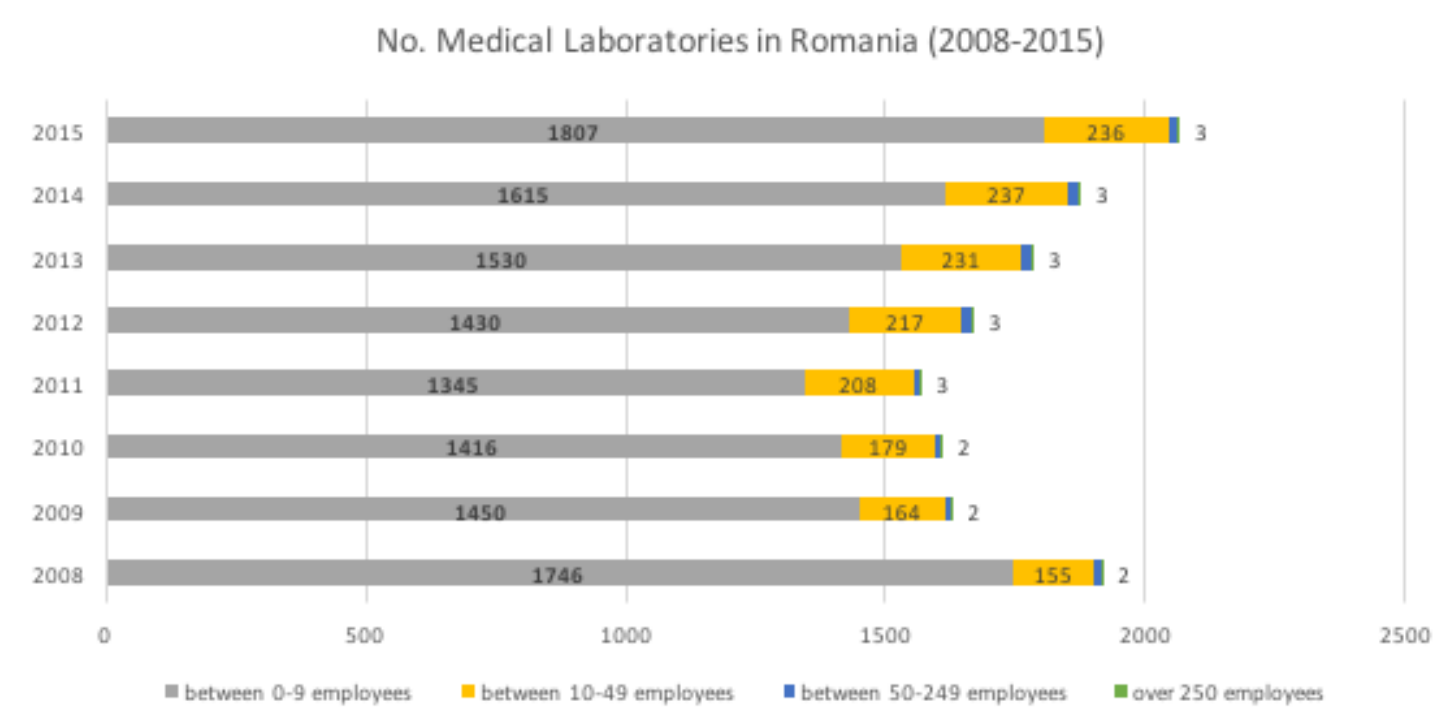

PICBE $\mid 1044$

Figure 4. No. of Medical Laboratories in Romania (2008-2013)

Source: compiled by the author from INSSE data

Table 1. Romanian cities with more than 10 private medical laboratory providers

\begin{tabular}{|l|c|}
\hline Bucuresti & 176 \\
\hline Iasi & 42 \\
\hline Craiova & 35 \\
\hline Constanta & 26 \\
\hline Cluj-Napoca & 25 \\
\hline Timisoara & 24 \\
\hline Targu Mures & 22 \\
\hline Ploiesti & 20 \\
\hline Brasov & 17 \\
\hline Galati & 17 \\
\hline Pitesti & 17 \\
\hline Sibiu & 17 \\
\hline Arad & 15 \\
\hline Bacau & 15 \\
\hline
\end{tabular}

Source: compiled by the author

The development of the private medical laboratories sector is mainly due to The National Health Assessment Program, hosted by the former Health Minister, Eugen Nicolaescu in which nearly 12.5 million people got a chance to freely do their blood tests. This led to an increasing growth of Laboratories, as all these tests were subsidized by the Romanian state. 
The majority of the medical laboratories in Romania are small enterprises, employing in between 1 and 9 persons. After the liberalisation in the national legislation, we can see a total number of small sized 1,746 medical laboratories in 2008, and after a subsequent decreasing trend due to inability to survive on the market, we now have a slightly higher number of small sized private medical laboratories in Romania: 1,807. While much fewer, the total number of average sized private medical laboratories (i.e. in between 10 and 49 employees) steadily increased, from 155 in 2008, to 236 in 2016. The number of large scale private medical laboratories in Romania is small: 3. Overall, the total number of private medical laboratories in Romania grew from 1,915 in 2008 to 2,065 in 2016.

If we look at the data in Table 1 , and Figure 5, we can see that the private medical laboratories market is significantly more fragmented than that of the dialysis services. Nevertheless, the highest concentration of economic actors in this subsector remains around large urban centres (e.g. Bucharest, Iasi) and/or large and performant medical centres (e.g. Tg. Mures).

Given the overall demographic challenges that Romania is currently facing, the smaller municipalities in Romania are increasingly left behind. These cities have fewer and fewer health care options, both from the public and from the private sector alike. In the public sector, the main challenge in securing accurate medical care is the scarce supply of medical personnel. As many of the Romanian cities are facing a severe challenge concerning outward migration ${ }^{7}$, the medical sector is often amongst the most inclined labour fields for brain-drain. As such, we often see municipalities that allocate significant resources to the renovation and refurbishment of medical clinics and hospitals in their jurisdiction (e.g. Bistrița, Oradea, Piatra Neamț, Timișoara), yet lack the human resources needed to provide adequate health care at the local level. In contrast, in the private sector we can often see a reversed dynamic, as many private medical laboratories are eager to invest in outposts in smaller municipalities, as the incomes derived from the public subsidies offered by the National Health Insurance House are attractive enough for owners to maintain their businesses here.

\footnotetext{
7 http://documents.worldbank.org/curated/en/327451497949480572/pdf/116400-WP-P158178-PUBLICMagneticCities-Jun18-v4.pdf
} 


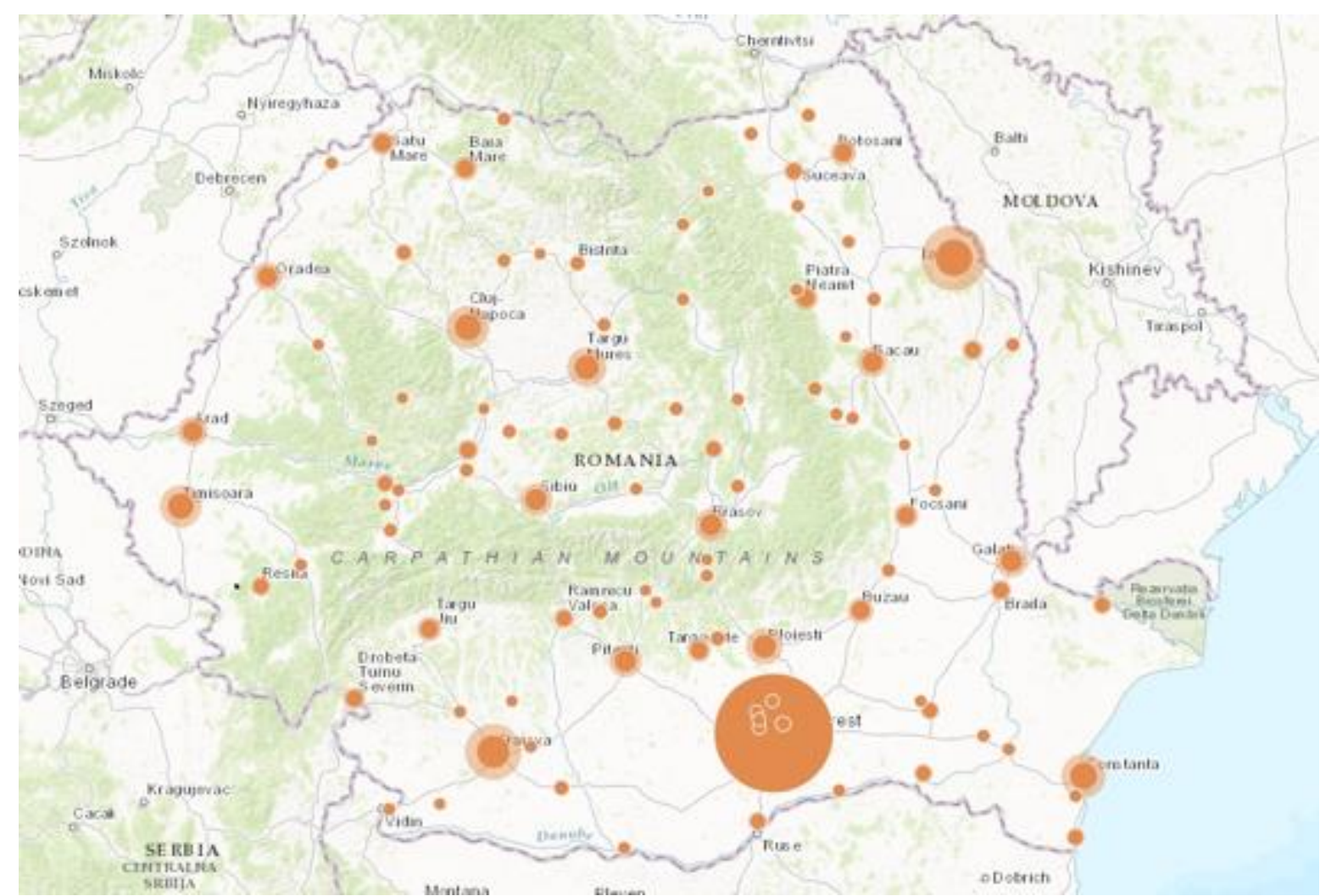

PICBE $\mid 1046$

Figure 5. Geographical Distribution of Medical Laboratories in Romania (2016)

Source: compiled by the author

\section{Conclusion and policy implications}

The private healthcare sector in Romania is currently one of the most profitable sectors for private investments. Following larger European tendencies, in the aftermath of the financial crisis (and the austerity measures in ensued), and given a larger trend of liberalisation of public service market, the healthcare sector in Romania is primed for internationalisation action of specialised foreign multinational companies and/or private equity investments.

The private medical services market in Romania remains highly concentrated around large players. In the general medical care sector, we see the dominance of 5 companies whose strategy is clearly focused on growth and increasing both the scale of their supply and their territorial coverage. Some rely mainly on private sector capital, others like Regina Maria have applied successfully for BEI funding. Certain legislative provisions have had a profound impact on the development of the private sector suppliers of dialysis services, and laboratory medical services in Romania. But, this impact is limited in scope, being mostly concentrated in profitable local markets such as urban areas in the case of medical laboratories. In the case of dialysis services the market is getting ever more concentrated, as the main players engaged in acquisitions of domestic actors to consolidate their already strong market share.

The main limitation of the present research steams from the poor availability of quantitative data concerning the medical sector in Romania. In general, we have a poor availability of data on private actors at the local level, and the national data (i.e. National Office for Trade Register (ONRC) ) is only available to public institutions, and not for academic purposes. If we want to compile various indicators of economic performance in the private health care provision sector (e.g. turnover, profits, number of employees, quantum of public subsidy) we have to trace the private health care providers on a 
company to company basis, and a large-scale analysis is rendered extremely difficult. Furthermore, the large private health care providers that also offer hospital services (i.e. Medlife, Regina Maria, Medicover, Sanador and Gral Medical) have a rampant economic expansion that is driven by a company strategy of reinvestments. If we want to assess the overall profitability of such companies in Romania, we have to approximate their declared profits coupled with the scale of reinvestments that take place annually in these holdings.

\section{Bibliography}

Crespy, A., \& Menz, G. (2015). Commission Entrepreneurship and the Debasing of Social Europe before and after the Eurocrisis. JCMS: Journal of Common Market Studies, 53(4), 753-768.

Goschin, Z., Constantin, D. L., Roman, M., \& Ileanu, B. V. (2009). Specialisation and concentration patterns in the Romanian economy. Journal of applied quantitative methods, 4(1), 95-111.

Hermann, C., \& Flecker, J. (Eds.). (2013). Privatization of public services: impacts for employment, working conditions, and service quality in Europe. Routledge.

Horobeț, A. \& Popovici, O. (2017) Investițiile străine directe: Evoluția și importanța lor în România, Foreign Investors Council (FIC) Study, accessible at http://www.fic.ro/Documents/view/Studiu-Investitiile-straine-directe-evolutiasi-importanta-lor-in-Romania

Jaehrling, K. (2015). The state as a 'socially responsible customer'? Public procurement between market-making and market-embedding. European Journal of Industrial Relations, 21(2), 149-164.

Karanikolos, M., Mladovsky, P., Cylus, J., Thomson, S., Basu, S., Stuckler, D. \& McKee, M. (2013). Financial crisis, austerity, and health in Europe. The Lancet, 381(9874), 1323-1331.

Mori, A. (2015). Outsourcing public services: local government in Italy, England and Denmark. The outsourcing challenge, 137.

Nikolic, I. and Maikisch, H. (2006) Public-Private Partnerships and Collaboration in the Health Sector: An Overview with Case Studies from Recent European Experience. Health, Nutrition and Population (HNP) Discussion Paper, World Bank Publications.

Preker, A. S., \& Feachem, R. G. (1995). Market mechanisms and the health sector in Central and Eastern Europe (Vol. 293). World Bank Publications.

Saltman, R. B., Figueras, J., \& Sakellarides, C. (1998). Critical challenges for health care reform in Europe. McGraw-Hill Education (UK).

Volintiru, M. (2016) The Role of the Private Sector in Delivering Public Health Services in Romania, Paper prepared for the "Competition and Competitiveness in European Regions and Cities" Workshop, 19th -20th of May 2016, ASE, Bucharest

Volintiru, M. (2017) International Standards and Private Health Services in Romania. EGE 2017 Conference Paper 